\title{
Agrobacterium-MEDIATED TRANSFORMATION OF Citrus sinensis AND Citrus limonia EPICOTYL SEGMENTS
} \author{
Madalena Januzzi Mendes 2,5 ; Alexandra Pavan ${ }^{3,6}$; Adriana Pinheiro Martinelli Rodriguez ${ }^{2}$ \\ ${ }^{1}$ Depto. de Produção Vegetal - USP/ESALQ, C.P. 9 - CEP: 13418-900 - Piracicaba, SP. \\ ${ }^{2}$ Lab. de Biotecnologia Vegetal - USP/CENA, C.P. 96 - CEP: 13400-970 - Piracicaba, SP. \\ ${ }^{3}$ UNIMEP - Rod. do Açúcar, Km. 156 - CEP: 13400-911 - Piracicaba, SP. \\ ${ }^{4}$ CAPES Fellow. \\ ${ }^{5} \mathrm{CNPq}$ Fellow. \\ ${ }^{6}$ FUNDECITRUS Fellow. \\ *Corresponding author <famourao@esalq.usp.br>
}

Weliton Antonio Bastos de Almeida 1,4; Francisco de Assis Alves Mourão Filho ${ }^{1,5 *}$; Beatriz

\begin{abstract}
Genetic transformation allows the release of improved cultivars with desirable characteristics in a shorter period of time and therefore may be useful in citrus breeding programs. The objective of this research was to establish a protocol for genetic transformation of Valencia and Natal sweet oranges ( Citrus sinensis $\mathrm{L}$. Osbeck) and Rangpur lime (Citrus limonia L. Osbeck). Epicotyl segments of germinated in vitroplantlets (three weeks in darkness and two weeks in a 16-h photoperiod) were used as explants. These were cocultivated with Agrobacterium tumefaciens strain EHA-105 and different experiments were done to evaluate the transformation efficiency: explants were co-cultivated with Agrobacterium for one, three or five days; explants were incubated with Agrobacterium suspension for 5, 10, 20 or 40 minutes; co-cultivation medium was supplemented with acetosyringone at 0,100 or $200 \mu \mathrm{mol} \mathrm{L}^{-1}$; Explants ends had a longitudinal terminal incision (2-3 mm); co-cultivation temperatures of 19,23 or $27^{\circ} \mathrm{C}$ were imposed. The experimental design was completely randomized in all experiments with five replications, each consisted of a Petri dish ( $100 \times 15 \mathrm{~mm})$ with 30 explants and resulted in a total of 150 explants per treatment. Longitudinal terminal incision in the explant ends did not improve shoot regeneration. However, transgenic plants of all three cultivars were confirmed from explants that had been subjected to inoculation time of 20 minutes, co-culture of three days at $23-27^{\circ} \mathrm{C}$, in the absence of acetosyringone.
\end{abstract}

Key words: genetic transformation, organogenesis, micrografting, improvement

\section{TRANSFORMAÇÃO GENÉTICA EM Citrus sinensis E Citrus limonia MEDIADA POR Agrobacterium tumefaciens A PARTIR DE SEGMENTOS DE EPICÓTILO}

\begin{abstract}
RESUMO: A transformação genética permite produzir cultivares com características específicas e pode, dessa forma ser associada a programas de melhoramento de citros. O objetivo deste trabalho foi estabelecer protocolos de transformação genética para as laranjas doce 'Valência' e 'Natal' (Citrus sinensis L. Osbeck), bem como para o limão 'Cravo'( Citrus limonia L. Osbeck). Segmentos de epicótilo de plântulas germinadas in vitro (três semanas no escuro e duas semanas sob fotoperíodo de 16h) foram utilizados como explantes. Estes foram co-cultivados comAgrobacterium tumefaciens (EHA-105), realizando-se vários experimentos para avaliar a eficiência do processo de transformação genética: explantes co-cultivados por um, três e cinco dias; tempo de inoculação com a bactéria de 5, 10, 20 e 40 minutos; co-cultivo em meio de cultura contendo 0,100 e $200 \mu \mathrm{mol} \mathrm{L}^{-1}$ de acetoseringona; Incisão longitudinal (2-3 mm) nas extremidades do explante; temperatura de co-cultivo 19,23 e $27^{\circ} \mathrm{C}$. Todos os experimentos consistiram de cinco repetições por tratamento, sendo cada repetição representada por uma placa de Petri contendo 30 explantes, perfazendo um total de 150 explantes por tratamento. Plântulas transgênicas dos três cultivares foram obtidas utilizando-se tempo de inoculação de 20 minutos, co-cultivo comAgrobacterium tumefaciens (EHA-105) por três dias, na ausência de acetoseringona no meio de cultura de co-cultivo e temperatura de co-cultivo de $23-27^{\circ} \mathrm{C}$. A incisão longitudinal na extremidade do explante favoreceu à organogênesein vitro, mas quando co-cultivado com Agrobacterium não houve regeneração de brotações.

Palavras-chave: transformação genética, organogênese, microenxertia, melhoramento
\end{abstract}

\section{INTRODUCTION}

The genus Citrus presents limitations for improvement via conventional breeding, and are directly associated with the reproductive biology of Citrus, such as nucellar polyembryony, a high level of heterozygosity and a long juvenile period (Grosser \&
Gmitter, 1990). Biotechnological techniques such as cell and tissue cultures and molecular biology have helped breeders to overcome these difficulties. In addition, the hybridization through protoplast fusion and genetic transformation may contribute significantly to avoid these limitations (Mendes-da-Glória et al., 2000). 
Genetic transformation has become an attractive alternative method for improving Citrus and other species because it is possible to maintain cultivar integrity while adding a single trait (Bond \& Roose, 1998). However, for efficient transgenic plant production, a previously defined tissue culture system for plant regeneration (Brasileiro \& Dusi, 1999) associated with a genetic transformation system for gene introduction is needed (Pérez-MolpheBalch \& Ochoa-Alejo, 1998). For Citrus, there are many in vitro protocols such as callus and cell suspension cultures (Cabasson et al., 1995), organogenesis induction (Pérez-Molphe-Balch \& Ochoa-Alejo, 1997), somatic embryogenesis induction (Tomaz et al., 2001), and protoplast isolation (Mendes et al., 2001) that are viable for use with genetic engineering protocols.

Citrus transformation was initially reported more than a decade ago (Kobayashi \& Uchimaya, 1989; Hidaka et al., 1990; Vardi et al., 1990; Moore et al., 1992). However, the success in the recovery of transgenic plants at that time was relatively inefficient due to many factors. Low transformation efficiency (Peña et al., 1995a), the growth of escapes even under selection (Yang et al., 2000), difficulties in rooting of transgenic shoots and genotypic influence (Gutiérrez-E. et al., 1997) are among the limiting factors for the development of transgenic citrus plants.

GUS and nptll have been used as reporter and selection genes, respectively on Citrus genetic transformation. There are a few reports about the introduction of genes of agronomic importance in Citrus, including the gene that encodes for the Citrus tristeza virus coat protein (Gutiérrez-E. et al., 1997; Domínguez et al., 2000; Yang et al., 2000), the HAL2 gene that confers tolerance to salinity (Cervera et al., 2000), LEAFY and APETALA1 genes that promote early flower initiation (Peña et al., 2001), and CS-ACS1 gene that controls the ethylene biosynthesis in Citrus (Wong et al., 2001). Reports on genetic transformation of the main cultivars used in the Brazilian citrus industry are very few (Mendes et al., 2002) and there are no reports of genetic transformation of the mostly used rootstock in Brazil, the Rangpur lime.

The goal of the present work is to establish efficient protocols for genetic transformation of two sweet orange varieties Natal and Valencia and the rootstock, Rangpur lime.

\section{MATERIAL AND METHODS}

Plant material:Seeds were extracted from ripe fruits of Valencia and Natal sweet oranges (Citrus sinensis L. Osbeck) and Rangpur lime (Citrus limonia L. Osbeck) and dried at room temperature for 24-h. The seed integument was removed and desinfestation was done in a $67 \%$ commercial sodium hypochlorite solution $(2.5 \%$ active chlorine) for 15 minutes followed by three rinses in distilled and sterilized water. The seeds were placed in test tubes $(150 \times 25 \mathrm{~mm})$ containing $15 \mathrm{~mL}$ of MT medium (Murashige \& Tucker, 1969) and maintained at $27 \pm 2^{\circ} \mathrm{C}$ in the dark for three weeks followed by one week in a 16-hour photoperiod $\left(40 \mu \mathrm{mol} \mathrm{m} \mathrm{m}^{-2}\right)$. Epicotyl segments approximately $1.0-\mathrm{cm}$-long were collected for the transformation experiments.

Agrobacterium strain: Agrobacterium tumefaciens strain EHA-105 carrying the plasmid p35SGUSINT was used. The bacteria were cultivated in solid YEP medium $(10 \mathrm{~g}$ $\mathrm{L}^{-1}$ peptone, $10 \mathrm{~g} \mathrm{~L}^{-1}$ yeast extract, $5 \mathrm{~g} \mathrm{~L}^{-1}$ sodium chloride, $15 \mathrm{~g} \mathrm{~L}^{-1}$ agar) containing kanamycin (100 $\left.\mathrm{mg} \mathrm{L}^{-1}\right)$ and rifampicin (50 $\left.\mathrm{mg} \mathrm{L}^{-1}\right)$, for 48 -h. After that, a single colony was transferred to a $250 \mathrm{~mL}$ Erlenmeyer flask with $50 \mathrm{~mL}$ of liquid YEP medium, supplemented with antibiotics and cultivated at $180 \mathrm{rpm}$ at $28^{\circ} \mathrm{C}$ for $16-\mathrm{h}$. The bacterial suspension was centrifuged at $4800 \mathrm{rpm}\left(5^{\circ} \mathrm{C} / 20 \mathrm{~min}\right)$ and resuspended in liquid MS medium (Murashige \& Skoog, 1962).

Transformation, selection, and regeneration: Epicotyl segments were incubated with the bacteria solution for 20 minutes. Following incubation, explants were blotted dry and plated on regeneration EME medium (Grosser \& Gmitter, 1990) supplemented with $25 \mathrm{~g} \mathrm{~L}^{-1}$ sucrose and 1.0 and $2.0 \mathrm{mg} \mathrm{L}^{-1}$ benzylaminopurine (BAP) for sweet orange cultivars and for Rangpur lime, respectively, in the dark at $27^{\circ} \mathrm{C}$ for a 3-day period. After co-culture, segments were transferred to regeneration medium, supplemented with kanamycin $\left(100 \mathrm{mg} \mathrm{L}^{-1}\right)$ and cefotaxime (500 $\left.\mathrm{mg} \mathrm{L}^{-1}\right)$. Explants were subcultured every 2 weeks. Developed shoots were transferred to EME medium supplemented with $\mathrm{GA}_{3}\left(1.0 \mathrm{mg} \mathrm{L}^{-1}\right)$, kanamicin $\left(100 \mathrm{mg} \mathrm{L}^{-1}\right)$ and cefotaxime $\left(500 \mathrm{mg} \mathrm{L}^{-1}\right)$ for elongation. Shoot basal ends and leaf segments were assayed for GUS activity. GUS ${ }^{+}$shoots were micrografted onto Carrizo citrange (C. sinensis L. Osbeck $\times$ Poncirus trifoliata $\mathrm{L}$. Raf.) seedlings. After 45 days, well-developed in vitro grafted plantlets were transferred to a commercial substrate (Rendmax Citrus ${ }^{\mathrm{TM}}$ ) and kept under high relative humidity for 30 days for acclimatization. In order to investigate the main factors affecting the transformation efficiency, different treatments were performed such as: 1) Co-cultivation of epicotyl segments with Agrobacterium for 1,3 or 5 days; 2) Explant incubation with Agrobacterium for 5, 10, 20 or 40 minutes; 3) Addition of acetosyringone at 0,100 or $200 \mu \mathrm{mol} \mathrm{L}^{-1}$ in the cocultivation medium; 4 ) Longitudinal terminal incision (2$3 \mathrm{~mm}$ ) in the explant; 5) Co-cultivation temperatures of 19,23 or $27^{\circ} \mathrm{C}$.

The experimental design was completely randomized, with five replications, each consisting of one Petri dish $(100 \times 15 \mathrm{~mm})$ with 30 explants resulting in a total of 150 explants per treatment for all experiments. Percent of explants with adventitious shoots were evaluated. Data were subjected to ANOVA at $1 \%$. Means were compared by Tukey's multiple range test. 
Analysis of putatively transformed tissue: leaves and stem segments were excised from 1-2-cm plants. Segments were incubated in the dark at $37^{\circ} \mathrm{C}$ for $24-\mathrm{h}$ in an X-Gluc solution (Jefferson, 1987) for âglucuronidase assay (GUS). For histological GUS assay, stem segments were fixed in paraformaldehyde $(3 \% \mathrm{~W} /$ v) and glutaraldehyde $(2 \% \mathrm{v} / \mathrm{v})$ in cacodylate buffer $(0.2$ $\mathrm{M}, \mathrm{pH}$ 7.2) with the first hour being in low vacuum. Fixed tissues were rinsed in buffer and slowly dehydrated at room temperature in a series of methyl cellosolve, ethanol, propanol and butanol followed by overnight infiltration at $4^{\circ} \mathrm{C}$ in butanol:infiltration medium (Historesin ${ }^{\mathrm{TM}} /$ Leica) (1:1). Infiltration was completed with $100 \%$ infiltration medium for 24-h or until the samples sank to the bottom of the flask. Polymerization was done at room temperature for 24 to 48 -h. Transverse serial sections $\left(5 \mathrm{~mol} \mathrm{~L}^{-1}\right)$ were prepared in a rotary microtome (Leica RM 2155) with a steel knife, the sections floated in water drops and dried on a hot plate $\left(40^{\circ} \mathrm{C}\right)$.

For the detection of specific T-DNA sequences, DNA was extracted from leaves of in vitro plantlets (Doyle \& Doyle, 1990). PCR amplification was performed using 50-100 ng of DNA, $200 \mu \mathrm{mol} \mathrm{L}^{-1}$ of dNTP, $2.5 \mathrm{mM} \mathrm{MgCl}$, $2 \mathrm{U}$ taq DNA polymerase (Promega) and $0.1 \mathrm{~mol} \mathrm{~L}^{-1} \mathrm{nptII}$ primer. The primers 5'GAG GCT ATT CGG CTA TGA CTG'3 and 5'ATC GGG AGC GGC GAT ACC GAT A'3 (Bond \& Roose, 1998) were used to amplify a $700 \mathrm{bp}$ specific fragment of nptll gene. Samples were heated to $94^{\circ} \mathrm{C}$ for $4 \mathrm{~min}$ followed by 30 cycles of $2 \mathrm{~min}$ at $96^{\circ} \mathrm{C}, 2$ $\min$ at $50^{\circ} \mathrm{C}$ and $3 \mathrm{~min}$ at $72^{\circ} \mathrm{C}$.

\section{RESULTS AND DISCUSSION}

Citrus genetic transformation has been preferentially obtained from explants collected from juvenile tissue. Agrobacterium has been the most frequently used genetic transformation system in Citrus with explants collected from seedlings germinated in vitro or under greenhouse conditions. Some authors used as explants, epicotyl segments excised from seedlings germinated in the dark for 3-6 weeks (Kaneyoshi et al., 1994; Bonde \& Roose, 1998; Luth \& Moore, 1999; Yang et al., 2000) and then transferred to a $16 \mathrm{~h}$ photoperiod that varied from 1 to 3 weeks (Cervera et al., 1998a; Peña et al., 1995a). Explants have been collected from seedlings germinated under light conditions for 2-4 months (Moore et al., 1992; Pérez-Molphe-Balch \& Ochoa-Alejo, 1998). Other authors have used internodal segments excised from seedlings cultivated in the greenhouse for 6-12 weeks (Peña et al., 1995b; 1997; Dominguez et al., 2000). In our work, the explants used were epicotyl segments excised from seedlings germinated in the dark for 3 weeks followed by 10-15 days under in a 16-h photoperiod. This explant type was chosen due to the high efficiency in shoot regeneration and efficient control of contamination as observed in an earlier study (Almeida et al., 2002).

The co-culture period has been reported as an important factor that may influence the genetic transformation process. Our results indicate that GUS ${ }^{+}$ shoots were recovered only when co-cultivation was done for 3 days (Table 1). An overgrowth of the bacteria after five days of co-cultivation was detected similar to that reported by Cervera et al. (1998b).

Another important factor in the genetic transformation efficiency is the period of inoculation of explants with Agrobacterium. In this work, a 20-min incubation time resulted in higher number of $\mathrm{GUS}^{+}$shoot recovered for all varieties (Table 2). Yang et al. (2000) also used 20 minutes of inoculation but did not compare different periods of inoculation.

Several authors have reported the supplementation of the co-culture medium with substances that stimulate the infection with Agrobacterium. Acetosyringone has been the most used for this propose at a concentration of $100 \mu \mathrm{mol} \mathrm{L}^{-1}$. In our study, acetosyringone at either 100 or $200 \mu \mathrm{mol} \mathrm{L}^{-1} \mathrm{did}$ not favor genetic transformation and the best results were observed in the absence of acetosyringone (Table 3). The liberation of phenolic compounds by the explants was probably enongh to favor Agrobacterium infection. Therefore, the exogenous supply of acetosyrigone when combined with endogenous phenolic compounds may have contributed negatively to the infection. Similar results were observed by Peña et al. (1995a) in Carrizo citrange when $\mathrm{GUS}^{+}$shoots were regenerated in the

Table 1 - Co-culture period of epicotyl segments with Agrobacterium (time of inoculation $=15$ minutes at $27^{\circ} \mathrm{C}$ ) versus bud differentiation and regeneration of $\mathrm{GUS}^{+}$plants of Natal and Valencia sweet oranges and Rangpur lime.

\begin{tabular}{|c|c|c|c|c|c|c|}
\hline \multirow{3}{*}{$\begin{array}{l}\text { Co-culture } \\
\text { period }\end{array}$} & \multicolumn{6}{|c|}{ Varieties } \\
\hline & \multicolumn{2}{|c|}{ Natal } & \multicolumn{2}{|c|}{ Valencia } & \multicolumn{2}{|c|}{ Rangpur } \\
\hline & $\begin{array}{c}N^{\circ} \text { expl. with } \\
\text { buds/total expl. }\end{array}$ & $\begin{array}{c}\text { GUS }{ }^{+} \\
\text {/analyzed } \\
\text { shoots } \\
\end{array}$ & $\begin{array}{l}\mathrm{N}^{\circ} \text { expl. with } \\
\text { buds/total expl. }\end{array}$ & $\begin{array}{c}\text { GUS }^{+} \\
\text {/analyzed } \\
\text { shoots }\end{array}$ & $\begin{array}{c}\mathrm{N}^{\circ} \text { expl. with } \\
\text { buds/total expl. }\end{array}$ & $\begin{array}{c}\text { GUS + } \\
\text { /analyzed } \\
\text { shoots }\end{array}$ \\
\hline days & 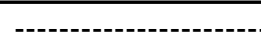 & 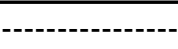 & - & 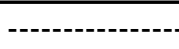 & 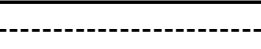 & - \\
\hline 1 & $21 / 150(14.0) \mathrm{C}$ & $00 / 16(0.0)$ & $26 / 150(17.3) b$ & $00 / 11(0.0)$ & $16 / 150(10.6) b$ & $00 / 07(0.0)$ \\
\hline 3 & $52 / 150(34.6) \mathrm{a}$ & $02 / 37(5.4)$ & $59 / 150(39.3) \mathrm{a}$ & $01 / 21(4.7)$ & $34 / 150(22.6) \mathrm{a}$ & $00 / 19(0.0)$ \\
\hline 5 & $32 / 150(21.3) b$ & $00 / 24(0.0)$ & $33 / 150(22.0) b$ & $00 / 19(0.0)$ & $15 / 150(10.0) b$ & $00 / 09(0.0)$ \\
\hline
\end{tabular}

Values for percent followed by the same letter do not differ (Tukey, 0.01). 
absence of acetosyringone in the culture medium. However, other authors report transgenic plant recovery using acetosyringone at $100 \mu \mathrm{mol} \mathrm{L}^{-1}$ in Pineapple sweet orange (Citrus sinensis L. Osbeck) (Cervera et al., 1998a) and Duncan grapefruit (Citrus paradisi) (Luth \& Moore, 1999) and $200 \mu \mathrm{mol} L^{-1}$ in Washington navel sweet orange (Citrus sinensis L. Osbeck) (Bond \& Roose, 1998). The response to acetosyringone could possibly be genotype-dependent.

Formation of meristematic regions or cell proliferation can be induced by cuts in the explant (Escudero \& Hohn, 1997). Anatomical characterization of organogenesis from epicotyl segments indicated that meristematic regions formed in the cambium were responsible for the formation of buds (data submitted for publication). With the goal of exposing the cambial region for a better contact with Agrobacterium, the explant ends were cut longitudinally $(2-3 \mathrm{~mm})$. This cut significantly favored the in vitro organogenesis and induced more buds per responsive explant when compared to the control (Table 4, Figures 1a-b). However, when the cut explants were co-cultivated with Agrobacterium, an overgrowth of bacteria did not allow shoot regeneration (Figure 1c). The contact of Agrobacterium with a larger number of exposed cells at the concentration used in this experiment $\left(5 \times 10^{8} \mathrm{UFC} \mathrm{\textrm {mL } ^ { - 1 }}\right)$ may have been too high, thereby favoring the overgrowth of bacteria and restricting shoot regeneration. A study with different concentrations of Agrobacterium may increase the transformation efficiency.

The temperature during co-cultivation had a significant effect on the stimulation of the vir region of the bacterial plasmid. This effect has also been reported in genetic transformation of several species where the best

Table 2 - Inoculation time of epicotyl segments with Agrobacterium (period of co-culture $=3$ days at $27^{\circ} \mathrm{C}$ ) versus bud differentiation and regeneration of GUS $S^{+}$plants of Natal and Valencia sweet oranges and Rangpur lime.

\begin{tabular}{|c|c|c|c|c|c|c|}
\hline \multirow{3}{*}{$\begin{array}{l}\text { Inoculation } \\
\text { time }\end{array}$} & \multicolumn{6}{|c|}{ Varieties } \\
\hline & \multicolumn{2}{|c|}{ Natal } & \multicolumn{2}{|c|}{ Valencia } & \multicolumn{2}{|c|}{ Rangpur } \\
\hline & $\begin{array}{c}\mathrm{N}^{\circ} \text { expl. with } \\
\text { buds/total expl. }\end{array}$ & $\begin{array}{c}\text { GUS + } \\
\text { /analyzed } \\
\text { shoots }\end{array}$ & $\begin{array}{c}\mathrm{N}^{\circ} \text { expl. with } \\
\text { buds/total expl. }\end{array}$ & $\begin{array}{c}\text { GUS }^{+} \\
\text {/analyzed } \\
\text { shoots }\end{array}$ & $\begin{array}{l}\mathrm{N}^{\circ} \text { expl. with } \\
\text { buds/total expl. }\end{array}$ & $\begin{array}{c}\text { GUS }^{+} \\
\text {/analyzed } \\
\text { shoots }\end{array}$ \\
\hline minutes & $---\cdot-$ & & (1) & & & \\
\hline 5 & $16 / 150(10.6) c$ & $00 / 09(0.0)$ & $14 / 150(9.3) d$ & $00 / 06(0.0)$ & 05/150(3.3) c & $00 / 03(0.0)$ \\
\hline 10 & $32 / 150(21.3) b$ & $00 / 23(0.0)$ & $28 / 150(18.6) c$ & $00 / 19(0.0)$ & $22 / 150(14.6) b$ & $00 / 15(0.0)$ \\
\hline 20 & $98 / 150(65.3) a$ & $10 / 86(11.6)$ & $79 / 150(52.6) a$ & $09 / 68(13.2)$ & $53 / 150(35.3) a$ & $00 / 36(0.0)$ \\
\hline 40 & $42 / 150(28.0) b$ & $00 / 29(0.0)$ & $46 / 150(30.6) b$ & $00 / 31(0.0)$ & $27 / 150(18.0) b$ & $00 / 19(0.0)$ \\
\hline
\end{tabular}

Values for percent followed by the same letter do not differ (Tukey, 0.01).

Table 3 - Acetosyringone concentration in the culture medium at co-culture (time of inoculation $=20$ minutes at $27^{\circ} \mathrm{C}$, and period of co-culture $=3$ days) versus bud differentiation and regeneration of GUS ${ }^{+}$plants of Natal and Valencia sweet oranges and Rangpur lime.

\begin{tabular}{|c|c|c|c|c|c|c|}
\hline \multirow{3}{*}{$\begin{array}{l}\text { Acetosyringone } \\
\text { concentration }\end{array}$} & \multicolumn{6}{|c|}{ Varieties } \\
\hline & \multicolumn{2}{|c|}{ Natal } & \multicolumn{2}{|c|}{ Valencia } & \multicolumn{2}{|c|}{ Rangpur } \\
\hline & $\begin{array}{l}\text { No expl. with } \\
\text { buds/total expl. }\end{array}$ & $\begin{array}{c}\text { GUS }^{+} \\
\text {/analyzed } \\
\text { shoots } \\
\end{array}$ & $\begin{array}{l}\mathrm{N}^{\circ} \text { expl. with } \\
\text { buds/total expl. }\end{array}$ & $\begin{array}{c}\text { GUS }^{+} \\
\text {/analyzed } \\
\text { shoots }\end{array}$ & $\begin{array}{c}\mathrm{N}^{\circ} \text { expl. with } \\
\text { buds/total expl. }\end{array}$ & $\begin{array}{c}\text { GUS }^{+} \\
\text {/analyzed } \\
\text { shoots } \\
\end{array}$ \\
\hline$\mu \mathrm{M}$ & 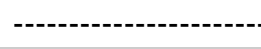 & 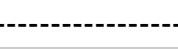 & \% & - & - & -----.-- \\
\hline 0 & $94 / 150(62.6) \mathrm{a}$ & $9 / 84(10.7)$ & $83 / 150(55.3) a$ & $09 / 65(13.8)$ & $50 / 150(33.3) a$ & $00 / 33(0.0)$ \\
\hline 100 & $89 / 150(59.3) a$ & $00 / 45(0.0)$ & $68 / 150(45.3) b$ & $00 / 42(0.0)$ & $49 / 150(32.6) \mathrm{a}$ & $00 / 32(0.0)$ \\
\hline 200 & $93 / 150(62.0) \mathrm{a}$ & $00 / 38(0.0)$ & $72 / 150(48.0) a b$ & $00 / 47(0.0)$ & $41 / 150(27.3) \mathrm{a}$ & $00 / 29(0.0)$ \\
\hline
\end{tabular}

Values for percent followed by the same letter do not differ (Tukey, 0.01).

Table 4 - Effect of the longitudinal cut $(2-3 \mathrm{~mm})$ in the explant ends on in vitro organogenesis of Natal and Valencia sweet oranges and Rangpur lime.

\begin{tabular}{|c|c|c|c|c|c|c|}
\hline \multirow{3}{*}{ Treatment } & \multicolumn{6}{|c|}{ Varieties } \\
\hline & \multicolumn{2}{|c|}{ Natal } & \multicolumn{2}{|c|}{ Valencia } & \multicolumn{2}{|c|}{ Rangpur } \\
\hline & Expl. with buds & Buds/expl. & Expl. with buds & Buds/expl. & Expl. with buds & Buds/expl. \\
\hline & $\%$ & mean & $\%$ & mean & $\%$ & mean \\
\hline Control & $92.6 \mathrm{a}$ & $286 / 139(2.1) b$ & $88.0 \mathrm{a}$ & $272 / 132$ (2.1) b & $77.0 \mathrm{a}$ & $212 / 116(1.8) b$ \\
\hline Cut Explants & $94.0 \mathrm{a}$ & $435 / 141(3.1) a$ & $91.0 \mathrm{a}$ & $421 / 137$ (3.1) a & $82.0 \mathrm{a}$ & $321 / 123(2.6) \mathrm{a}$ \\
\hline
\end{tabular}

Values for percent followed by the same letter do not differ (Tukey, 0.01). 
temperature was $22^{\circ} \mathrm{C}$ for Phaseolus acutifolius and Nicotiana tabacum (Dillen et al., 1997) and was of 22$24^{\circ} \mathrm{C}$ for Lycopersicum sculentum (Costa et al., 2000). Fullner \& Nester (1996) studied the T-DNA transfer ability of several Agrobacterium tumefaciens strains under different temperatures $\left(15\right.$ to $\left.31^{\circ} \mathrm{C}\right)$. In that case, the frequency of T-DNA transfer decreased with the increase in temperature suggesting that the T-DNA transfer is sensitive to higher temperatures. For Citrus genetic transformation, temperatures between $26-28^{\circ} \mathrm{C}$ have been used for co-cultivation. In this work, we evaluated the temperatures of 19,23 and $27^{\circ} \mathrm{C}$. The temperature of $23^{\circ} \mathrm{C}$ induced the best genetic transformation efficiency in Natal sweet orange and the best temperature for Valencia sweet orange genetic transformation was $27^{\circ} \mathrm{C}$. For Rangpur lime, GUS $^{+}$shoots were strongly dependent on the co-cultivation temperature and were obtained only when the co-cultivation temperature was $23^{\circ} \mathrm{C}$. However, these results suggest that T-DNA transfer is not only dependent on the temperature of co-cultivation but also upon a combination of different factors such as: temperature, genotype, co-cultivation period and inoculation time.

Genetic transformation in the same Citrus species has been considered as recalcitrant due to the low transformation efficiency (Moore et al., 1992; Peña et al., 1995b). Our studies confirm this fact. The highest percents of efficiency (GUS ${ }^{+} /$total explants) were $11.6 \%$ (Table 2), $13.8 \%$ (Table 3) and 19.3\% (Table 5) for Natal sweet orange, Valencia sweet orange and Rangpur lime, respectively. These numbers are relatively low, especially in sweet orange cultivars, when compared to our previous work with Hamlin orange where $81.5 \%$ of transformation efficiency was reported (Mendes et al., 2002).

The occurrence of shoot escapes was high. The regeneration of non-transformed plants can be explained by non-efficient selection due to the protection of nontransformed cells (Ghorbel et al., 1999). In addition, two chimeric plants of Natal sweet orange were obtained (Figures 2c, d). The regeneration of chimeric plants can be associated with the fact that adventitious buds have multicellular origin. Citrus chimeric plants were also described by other authors (Peña et al., 1997; GutiérrezE. et al., 1997; Cervera et al., 1998b).

GUS $^{+}$shoots (Figure $2 \mathrm{e}, \mathrm{f}, \mathrm{g}$ ) were in vitro grafted (Figure $2 \mathrm{~h}$ ) with $80 \%$ of bud-take efficiency. Histological sections (Figure 2g) showed the expression of GUS gene in the stem tissue, from the epidermis to the pith, confirming the GUS gene transfer to the cells responsible for shoot formation. Genetic transformation was also confirmed by PCR analysis with the presence of the 700 bp DNA fragments, corresponding to the nptll gene (Figure 2i). After they were grafted, the plants were acclimatized and transferred to the greenhouse (Figure 2j).

Our results confirm that transgenic plants of Natal and Valencia sweet orange and Rangpur lime can be obtained using a co-cultivation period of three days, inoculation time of 20 minutes, absence of
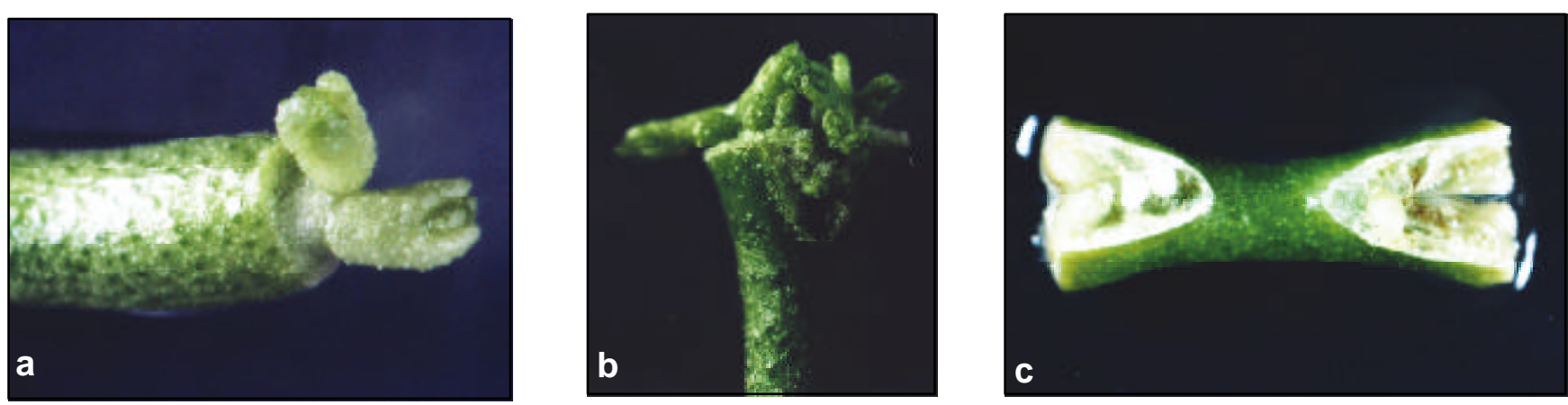

Figure 1 - Influence of explant cut on in vitro organogenesis and genetic transformation of Natal and Valencia sweet oranges and Rangpur lime. (a) control; (b) explant end with longitudinal incision; (c) explant cut longitudinally and co-cultivated with Agrobacterium.

Table 5 - Temperature of co-culture with Agrobacterium (time of inoculation $=20$ minutes and period of co-culture $=3$ days) versus bud differentiation and regeneration of GUS+ plants of Natal and Valencia sweet oranges and Rangpur lime.

\begin{tabular}{|c|c|c|c|c|c|c|}
\hline \multirow{3}{*}{$\begin{array}{l}\text { Temperature } \\
\text { of co-culture }\end{array}$} & \multicolumn{6}{|c|}{ Varieties } \\
\hline & \multicolumn{2}{|c|}{ Natal } & \multicolumn{2}{|c|}{ Valencia } & \multicolumn{2}{|c|}{ Rangpur } \\
\hline & $\begin{array}{c}\mathrm{N}^{\circ} \text { expl. with } \\
\text { buds/total expl. }\end{array}$ & $\begin{array}{c}\text { GUS }^{+} \\
\text {/analyzed } \\
\text { shoots }\end{array}$ & $\begin{array}{c}\mathrm{N}^{\circ} \text { expl. with } \\
\text { buds/total expl. }\end{array}$ & $\begin{array}{c}\text { GUS }^{+} \\
\text {/analyzed } \\
\text { shoots }\end{array}$ & $\begin{array}{l}\mathrm{N}^{\circ} \text { expl. with } \\
\text { buds/total expl. }\end{array}$ & $\begin{array}{c}\text { GUS }^{+} \\
\text {/analyzed } \\
\text { shoots }\end{array}$ \\
\hline${ }^{\circ} \mathrm{C}$ & 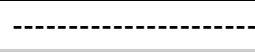 & 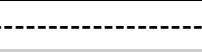 & - & 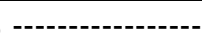 & - & - \\
\hline 19 & $48 / 150(32.0) b$ & $00 / 33(0,0)$ & $45 / 150(30.0) \mathrm{c}$ & $00 / 36(0.0)$ & $27 / 150(18.0) b$ & $00 / 21(0.0)$ \\
\hline 23 & $52 / 150(34.6) b$ & $04 / 35(11.5)$ & $58 / 150(38.6) b$ & $00 / 42(0.0)$ & $42 / 150(28.0) \mathrm{a}$ & 06/31(19.3) \\
\hline 27 & $93 / 150(62.0) \mathrm{a}$ & $7 / 86(8.1)$ & $74 / 150(49.3) a$ & $08 / 61(13.1)$ & $53 / 150(35.0) a$ & $00 / 39(0.0)$ \\
\hline
\end{tabular}

Values for percent followed by the same letter do not differ (Tukey, 0.01). 

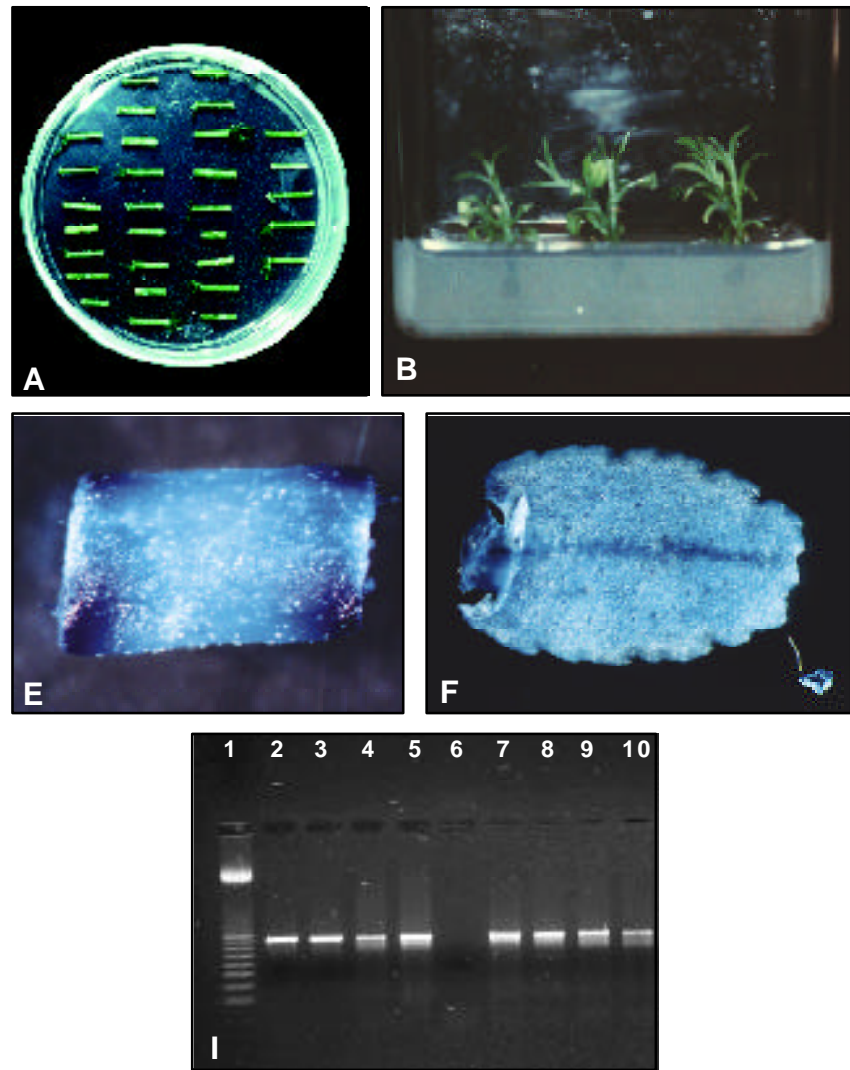
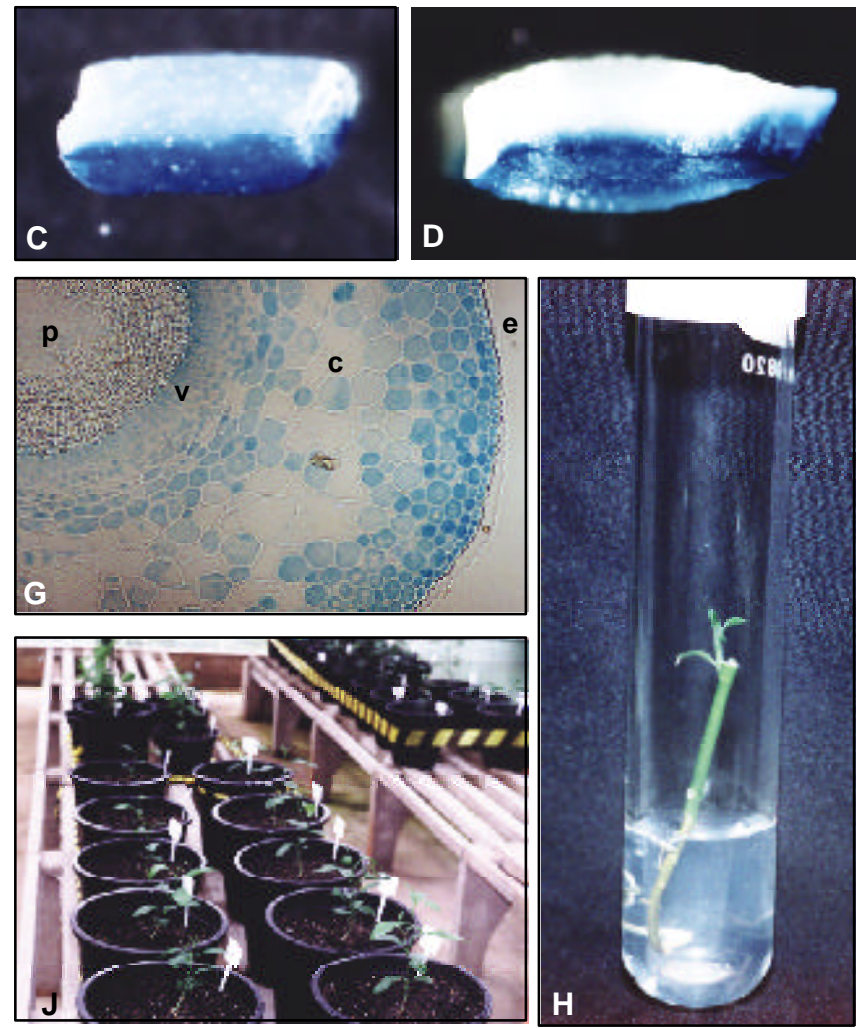

Figure 2 - Genetic transformation of Natal and Valencia sweet oranges and Rangpur lime using epicotyl segments as explants. (a) epicotyl segment after co-cultivation with Agrobacterium; (b) regenerated shoots cultivated in elongation medium; (c) stem segment; (d) stem segment showing possible chimeric plants after histochemical GUS assay; (e) stem; (f) and leaf segments; ( $g$ ) histological section showing GUS+ shoots after histochemical and histological GUS assay. e = epidermis; $c=c o r t e x ; ~ v=$ vascular cylinder; $p=$ pith; (h) GUS ${ }^{+}$shoots in vitro grafted on Carrizo citrange; (i) analysis of PCR of the GUS ${ }^{+}$DNA plants. Lane 1 = ladder $100 \mathrm{bp}$. Lane 2 = positive control consisting of the plasmid. Lane 6 = negative control consisting of non-transformed plant DNA. Lanes 3, 4, 5, 7, 8, 9 and $10=$ represent nptll plants; (j) transgenic plants in the greenhouse.

acetosyringone in the co-cultivation medium, and temperature of co-cultivation of $23^{\circ} \mathrm{C}$ and $27^{\circ} \mathrm{C}$, and $23^{\circ} \mathrm{C}$, respectively. In addition, the longitudinal cut $(2-3$ $\mathrm{mm}$ ) on the explant ends favored in vitro organogenesis but did not allow shoot regeneration after being cocultivated with Agrobacterium tumefaciens.

\section{ACKNOWLEDGEMENTS}

To Fundação de Amparo à Pesquisa do Estado de São Paulo (FAPESP) and Fundo Paulista de Defesa da Citricultura (Fundecitrus) for financial support.

\section{REFERENCES}

ALMEIDA, W.A.B.; MOURÃO FILHO, F.A.A.; MENDES, B.M.J.; RODRIGUEZ, A.P.M. In vitro organogenesis optimization and plantlet regeneration in Citrus sinensis and C. limonia. Scientia Agricola, v.59, p.35-40, 2002.

BOND, J.E.; ROOSE, M.L. Agrobacterium-mediated transformation of the commercially important citrus cultivar Washington navel orange. Plant Cell Reports, v.18, p.229-234, 1998.

BRASILEIRO, A.C.M.; DUSI, D.M.A. Transformação genética de plantas. In: TORRES, A.C.; CALDAS, L.S.; BUSO, J.A. (Ed.) Cultura de tecidos e tranformação genética de plantas. Brasília: Embrapa, SPI; Embrapa Hortaliças, 1999. v.2, p.679-735

CABASSON, C.; OLLITRAULT, P.; CÔTE, F.X.; FERRIERE, N.M.; DAMBIER, D.; DALNIC, R.; TEISSON, C. Characteristics of Citrus cell cultures during undifferentiated growth on sucrose and somatic embryogenesis on galactose. Physiologia Plantarum, v.93, p.464-470, 1995.
CERVERA, M.; NAVARRO, L.; PEÑA, L. Agrobacterium-mediated transformation of citrange: factors affecting transformation and regeneration. Plant Cell Reports, v.18, p.271-278, 1998a.

CERVERA, M.; JUÁREZ, J.; NAVARRO, A.; PINA, J.A.; DURAN-VILA, N.; NAVARRO, L.; PEÑA, L. Genetic transformation and regeneration of mature tissue of woody fruit plants bypassing the juvenile stage. Transgenic Research, v.7, p.51-59, 1998b.

CERVERA, M.; ORTEGA, C.; NAVARRO, A.; NAVARRO, L.; PEÑA, L. Generation of transgenic citrus plants with the tolerance-to-salinity gene HAL2 from yeast. Journal of Horticultural Science \& Biotechnology, v.75, p.26-30, 2000

COSTA, M.G.C.; NOGUEIRA, F.T.S.; OTONI, W.C.; BROMMONSSCHENKEL, S.H. Transformação genética de cultivares de tomateiro industrial mediada por Agrobacterium tumefaciens. Revista Brasileira de Fisiologia Vegetal, v.12, p.107-118, 2000

DILLEN, W.; DE CLERCQ, J.; GOOSSENS, A.; VAN MONTAGU, M.; ANGENON, G. Agrobacterium-mediated transformation of Phaseolus acutifolios A. Gray. The Plant Journal, v.12, p.1459-1463, 1997.

DOMÍNGUEZ, A.; GUERRI, J.; CAMBRA, M.; NAVARRO, L.; MORENO, P PEÑA, L. Efficient production of transgenic citrus plants expressing the coat protein gene of citrus trizteza virus. Plant Cell Reports, v.19, p.427$433,2000$.

DOYLE, J.J.; DOYLE, J.L. Isolation of plant DNA from fresh tissue. Focus, V.12, p.13-15, 1990.

ESCUDERO, J.; HOHN, B. Transfer and integration of T-DNA without cell injury in the host plant. The Plant Cell, v.9, p.2135-2142, 1997.

FULLNER, K.J.; NESTER, E.W. Temperature affects the T-DNA transfer machinery of Agrobacterium tumefaciens. Journal of Bacteriology, v.178, p.1498-1504, 1996.

GHORBEL, B.R.; JUÁREZ, J.; NAVARRO, L.; PEÑA, L. Green fluorescent protein as a screenable marker to increase the efficiency of generating woody fruit plants. Theoretical and Applied Genetics, v.99, p.350-358, 1999.

GROSSER, J.W.; GMITTER JR, F.G. Protoplast fusion and citrus improvement. Plant Breeding Reviews, v.8, p.339-374, 1990. 
GUTIÉRREZ-E., M.A.; LUTH, D.; MOORE, G.A. Factors affecting Agrobacterium-mediated transformation in Citrus and production of sour orange (Citrus aurantium) plants expressing the coat protein gene of Citrus tristeza virus. Plant Cell Reports, v.16, p.745-753, 1997.

HIDAKA, T.; OMURA, M.; UGAKI, M.; TOMIYAMA, M.; KATO, A.; OHSHIMA, M.; MOTOYOSHI, F. Agrobacterium-mediated transformation and regeneration of Citrus spp. from suspension cells. Japanese Journal of Breeding, v.40, p.199-207, 1990.

JEFFERSON, R.A. Assaying chimeric genes in plants: the GUS gene fusion system. Plant Molecular Biology Reporter, v.5, p.387-405, 1987.

KANEYOSHI, J.; KOBAYASHI, S.; NAKAMURA, Y. A simple and efficient gene transfer system of trifoliate orange. Plant Cell Reports, v.13, p.541-545, 1994.

KOBAYASHI, S.; UCHIMIYA, H. Expression and integration of a foreign gene in orange (Citrus sinensis L. Osbeck) protoplast by direct DNA transfer. Japanese Journal of Genetics, v.64, p.91-97, 1989.

LUTH, D.; MOORE, G. Transgenic grapefruit plants obtained by Agrobacterium tumefaciens-mediated transformation. Plant Cell, Tissue and Organ Culture, v.57, p.219-222, 1999

MENDES, B.M.J.; MOURÃO FILHO, F.A.A.; FARIAS, P.C.M.; BENEDITO, V.A. Citrus somatic hybridization with potential for improved blight and CTV resistance. In vitro Cellular Developmental Biology-Plant, v.37, p.490-495, 2001.

MENDES, B.M.J.; BOSCARIOL, R.L.; MOURÃO FILHO, F.A.A.; ALMEIDA, W.A.B. Agrobacterium-mediated transformation of citrus Hamlin cultivar (Citrus sinensis L. Osbeck) epicotyl segments. Pesquisa Agropecuária Brasileira, v.37, p.955-961, 2002

MENDES-DA-GLÓRIA, F.J.; MOURÃO FILHO, F.A.A., MENDES, B.M.J. Caipira sweet orange + rangpur lime: a somatic hybrid with potential for use as rootstock in the brazilian citrus industry. Genetics and Molecular Biology, v.23, p.661-665, 2000

MOORE, G.A.; JACANO, C.C.; NEIDIGH, J.L. Agrobacterium-mediated transformation of citrus stem segments and regeneration of transgenic plants. Plant Cell Reports, v.11, p.238-242, 1992.

MURASHIGE, T.; SKOOG, F. A revised medium for rapid growth and bioassays with tobacco tissue culture. Physiologia Plantarum, v.15, p.473-497, 1962.

MURASHIGE, T.; TUCKER, D.P.H. Growth factor requirement of citrus tissue culture. In: INTERNATIONAL CITRUS SYMPOSIUM, 1., Riverside, 1969. Proceedings. Riverside: University of California, 1969. v.3, p.1155-1169.

PEÑA, L.; CERVERA, M.; JUAREZ, J.; ORTEGA, C.; PINA, J.A.; DURÁNVILA, N.; NAVARRO, L. High efficiency Agrobacterium-mediated transformation and regeneration of citrus. Plant Science, v.104, p.183191, 1995a.
PEÑA, L.; CERVERA, M.; JUAREZ, J.; NAVARRO, A.; PINA, J.A.; DURÁNVILA, NAVARRO, L. Agrobacterium-mediated transformation of sweet orange and regeneration of transgenic plants. Plant Cell Reports, v.14, p.616-619, 1995b.

PEÑA, L.; CERVERA, M.; JUÁREZ, J.; NAVARRO, A.; PINA, J.A.; NAVARRO, L. Genetic transformation of lime (Citrus aurantifolia): factors affecting transformation and regeneration. Plant Cell Reports, v.16, p.731-737, 1997.

PEÑA, L.; MARTIN-TRILLO, M.; JUÁREZ, J.; PINA, J.A.; NAVARRO, L.; MARTINEZ-ZAPATER, J. Constitutive expression of Arabidopsis LEAFY or APETALA1 genes in citrus reduces their generation time. Nature Biotechnology, v.19, p.263-267, 2001.

PÉREZ-MOLPHE-BALCH, E.; OCHOA-ALEJO, N. In vitro plant regeneration of Mexican lime and mandarin by direct organogenesis. HortScience, v.32, p.931-934, 1997.

PÉREZ-MOLPHE-BALCH, E.; OCHOA-ALEJO, N. Regeneration of transgenic plants of Mexican lime from Agrobacterium rhizogenes-transformed tissues. Plant Cell Reports, v.17, p.591-596, 1998.

TOMAZ, M.L.; MENDES, B.M.J.; MOURÃO FILHO, F.A.A.; DEMÉTRIO, C.G.B.; JANSAKUL, N.; RODRIGUEZ, A.P.M. Somatic embryogenesis in Citrus spp.: carbohydrate stimulation and histodiferentiation. In vitro Cell Developmental Biology-Plant, v.37, p.446-452, 2001.

VARDI, A.; BLEICHMAN, S.; AVIV, D. Genetic transformation of citrus protoplast and regeneration of transgenic plants. Plant Science, v.69, p.199-206, 1990.

WONG, W.S.; LI, G.G.; NING, W.; XU, Z.F. HSIAO, W.L.W. ZHANG, L.Y $\mathrm{LI}, \mathrm{N}$. Repression of chilling-induced ACC accumulation in transgenic citrus by over-production of antisense 1-aminocyclopropane-1-carboxylate synthase RNA. Plant Science, v.161, p.969-977, 2001.

YANG, Z.N.; INGELBRECHT, I.L.; LOUZADA, E.; SKARIA, M.; MIRKOV, T.E. Agrobacterium-mediated transformation of the commercially important grapefruit cultivar Rio Red (Citrus paradisi Macf.). Plant Cell Reports v.19, p.1203-1211, 2000.

Received June 4, 2002 